\title{
Effect of the HIV protease inhibitor Amprenavir on the growth and differentiation of primary gingival epithelium
}

\author{
Mohd Israr ${ }^{1}$, Danielle Mitchell ${ }^{1}$, Samina Alam ${ }^{1}$, Donald Dinello², Joseph J Kishel ${ }^{3}$, and \\ Craig Meyers ${ }^{1, *}$ \\ ${ }^{1}$ Department of Microbiology and Immunology, The Pennsylvania State University College of \\ Medicine, 500 University Drive, Hershey, Pennsylvania 17033, USA \\ 2Oral Surgery Associates, 1253 Cocoa Ave, Hershey, Pennsylvania, USA \\ ${ }^{3}$ Department of Pharmacology, The Pennsylvania State University College of Medicine, 500 \\ University Drive, Hershey, Pennsylvania 17033, USA
}

\begin{abstract}
Background-Human immunodeficiency virus (HIV) positive patients taking antiretroviral drugs, including protease inhibitors have shown a significant increase in the development of oral complications, a major health issue for those patients. The effect of these drugs on oral epithelium growth and differentiation is presently unknown. In this study, we explore for the first time, the effect of HIV protease inhibitor Amprenavir on gingival epithelium growth and differentiation.
\end{abstract}

Methods-Organotypic (raft) cultures of gingival keratinocytes were established. Raft cultures were treated with a range of Amprenavir concentrations. Hematoxylin and eosin staining was performed to examine the effect of Amprenavir on gingival epithelium growth and stratification. Further, raft cultures were immunohistochemically analyzed to determine the effect of Amprenavir on the expression of key differentiation and proliferation markers including cytokeratins, PCNA and cyclin A.

Results-Amprenavir severely inhibited the growth of gingival epithelium when the drug was present throughout the growth period of the tissue. When drug was added at day 8, Amprenavir treatments altered the proliferation and differentiation of gingival keratinocytes. Expression of cytokeratins 5, 14, 6, 10, PCNA and cyclin A was increased, and their expression pattern was also altered over time in treated rafts. Therefore, biochemically the tissue exhibited characteristics of increased proliferation in the suprabasal layers of Amprenavir treated tissue.

Conclusions-Our results suggest that Amprenavir treatments deregulated the cell cycle/ proliferation and differentiation pathways resulting in abnormal epithelial repair and proliferation. Our system could be developed as a potential model for studying HIV/ highly active antiretroviral therapy (HAART) affects in vitro.

\section{Introduction}

Human immunodeficiency virus infection constitutes a major health problem worldwide. Globally, 33 million people currently live with HIV, mostly in developing countries including Latin America, South East Asia and particularly in sub-Saharan Africa [1]. Oral and perioral manifestations are common in HIV infected patients and often influence the debilating general health status and a worse prognosis of the disease $[2,3]$. The use of antiretroviral drugs, especially protease inhibitors have markedly reduced mortality and

*Corresponding author: Phone (717)531-6240. Fax (717)531-4600. cmm10@ psu.edu. 
increased the life expectancy of HIV positive patients [4,5]. In addition, there is a decrease in oral complications in these patients especially oral candidiasis and oral hairy leukoplakia [6,7]. In contrast, other complications such as Kaposi's sarcoma and oral apthous ulceration have shown no significant change [6-8]. Despite having many beneficial effects on HIV positive patients, HAART has been shown to have several adverse oral effects including the development of oral warts $[6,8]$, xerostomia $[9,10]$, erythema multiforme $[9,10]$, toxic epidermal necrolysis, lichenoid reactions [9,11], exfoliative cheilitis [9], oral ulceration and paresthesia $[10,12]$.

Amprenavir (trade name Agenerase) belongs to the class of anti-HIV drugs classified as protease inhibitors. In 1999, Amprenavir was approved by the U.S. Food and Drug Administration (FDA) for use in adults and children with HIV infection. This drug was shown to work by inhibiting the action of the HIV protease enzyme during viral replication thus preventing virion maturation, leading to the formation of noninfectious viral particles [13]. As with other protease inhibitors, prolonged use of Amprenavir reportedly associated with adverse orofacial effects including oral warts, perioral paresthesia, parotid lipomatosis, toxic epidermal necrolysis, Stevens-Johnson syndrome, xerostomia, and taste disturbance $[6,9,14-16]$. Good oral health is necessary for both quality of life and adherence to drug regimens. Decreased adherence correlates with suboptimal drug levels and consequent development of drug resistance which can compromise future therapy [17]. Therefore, any toxic side effects in the oral region due to long term use of antiretroviral drugs would have a major impact on the quality of life and adherence to therapy.

Cutaneous and mucosal epithelial tissues are the first line of defense from the environment. Damage to the epithelial layer allows microorganisms and toxic materials to access the underlying tissues. To help protect against damage to the epithelial lining, epithelial cells undergo a complex, well defined differentiation program resulting in the expression of numerous structural proteins whose design is to maintain the integrity and function of the epithelial tissues [18]. Despite the normal structural integrity and function, damage to the epithelial tissue still occurs. This is particularly evident in the oral cavity due to its masticatory function. Regional differences in epithelial turnover show that besides the small intestine, turnover of tissues is highest in the oral cavity [19]. Normally, this allows for a rapid wound healing response when the oral epithelial lining is compromised. Therefore, changes in the turnover rate of oral epithelium during treatment with HAART may affect acquisition of oral disease.

\section{Cytokeratins are the dominant proteins expressed in the epithelium and are the fundamental markers of epithelial differentiation}

The expression of specific cytokeratins appears to depend on the type of tissue as well as on the state of differentiation or development, and pathologic conditions [20,21]. Several studies have shown an alteration in the pattern of cytokeratins expression during tissue injury and the re-epithelialization process including the expression of differentiation associated cytokeratins as well as proliferation and wound healing related cytokeratins [2225].

Protease inhibitors including Amprenavir constitute several adverse oral complications and the effect of this drug on the growth and differentiation of oral epithelium has yet to be evaluated. In the present study, using the organotypic (raft) tissue culture model system derived from primary gingival cells, we explore for the first time the effect of Amprenavir on gingival epithelium growth, and the expression patterns of differentiation and proliferation markers. 


\section{Methods}

\section{Primary gingival keratinocytes and organotypic raft cultures}

Primary gingival keratinocytes were isolated from human gingival tissue. The mixed pool of gingival tissues was obtained from patients undergoing dental surgery. Approval to collect patient samples was obtained from the Penn State University College of Medicine Institutional Review Board (IRB\# 25284). The connective tissue and dermis was removed from the epithelium and discarded. The epithelial tissue was washed three times with PBS containing $50 \mu \mathrm{g} / \mathrm{ml}$ gentamycin sulfate (Gibco BRL, Bethesda, MD, USA) and 1X nystatin (Sigma Chemical Co., St. Louis, MO, USA). The epithelial tissue was then minced with scissors and trypsinized in a sterile glass universal containing a stir bar. The universal was placed on a magnetic stirrer at $37^{\circ} \mathrm{C}$ and stirred for $30 \mathrm{~min}$. The supernatant was removed, $20 \mathrm{ml}$ of E media plus 5\% FCS was added and cells were pelleted by centrifugation. The supernatant was aspirated and the cell pellet was resuspended in $1 \mathrm{ml}$ of 154 media (Cascade Biologics, Inc., Portland, OR, USA) then added to a $10 \mathrm{~cm}$ tissue culture plate containing an additional $7 \mathrm{ml}$ of 154 media. This process was repeated three times. When cultures reached $\approx 70 \%$ confluent they were split 1:3, when the plates of the first passage were more than $70 \%$ confluent, the cells were used for growing raft cultures.

Raft cultures were grown as previously described [26,27]. Briefly, mouse fibroblast 3T3 J2 were trypsinized and resuspended in 10\% reconstitution buffer, 10\% 10X DMEM (Life Technologies, Gaithersburg, MD, USA), $2.4 \mu \mathrm{l} / \mathrm{ml}$ of $10 \mathrm{M} \mathrm{NaOH}$, and $80 \%$ collagen (Dickinson, Franklin Lakes, NJ, USA) to a concentration of $2.5 \times 10^{5}$ cells $/ \mathrm{ml}$ on ice. The mixture was then aliquoted into 6 well plates at $2.5 \mathrm{ml}$ per well and incubated at $37{ }^{\circ} \mathrm{C}$ for $2-4 \mathrm{~h}$ to allow solidification of the collagen matrices. Two $\mathrm{ml}$ E-media was then added to each well to allow the matrix to equilibrate. Human gingival epithelial keratinocytes were trypsinized and resuspended at $1 \times 10^{6}$ cells $/ \mathrm{ml}$ in E-media and $1 \mathrm{ml}$ of cell suspension was added to each well of the 6 well plate on top of the collagen matrices from above. Epithelial cells were allowed to attach to the dermal equivalent for $2-4 \mathrm{~h}$. After removal of media, the collagen matrices were lifted onto stainless steel grids at the air-liquid interface. The raft cultures were fed by diffusion from below with E-media supplemented with Amprenavir. Amprenavir oral solution $15 \mathrm{mg} / \mathrm{ml}$ (GlaxoSmithKline) was purchased from the Pharmacy at The Milton S. Hershey Medical Center, Penn State University. The required volume of drug was directly mixed in E-media. The $\mathrm{C}_{\max }$ (peak concentration of a drug in blood after its administration) of Amprenavir is $7.66 \mu \mathrm{g} / \mathrm{ml}$ (GlaxoSmithKline, Research Triangle Park, NC 27709). We chose to use two lower and two higher concentrations from the $C_{\max }$ for our treatments. In the first set of experiments, the rafts were treated with Amprenavir at concentrations of 2, 5, 7.66, 9 and $12 \mu \mathrm{g} / \mathrm{ml}$ from the first day. Control rafts were fed with E-media only. The rafts were fed every other day and harvested at day 4, 8, 12 and 16.

In the second set of experiments, the rafts were fed with E-media only for 7 days and on the day $8^{\text {th }}$ the rafts were treated with Amprenavir at the concentrations stated above. The rafts were fed every other day and harvested at 2, 4, 6 and 8 days post treatment.

\section{Histochemical analyses}

Raft cultures were fixed in $10 \%$ buffered formalin, and embedded in paraffin. Four micrometer sections were cut and stained with hematoxylin and eosin as described previously [26].

Immunostaining was performed with the Vectastain Elite $\mathrm{ABC}$ kit (Vector laboratories Burlingame, CA, USA) [26]. Briefly, slides were baked at $55^{\circ} \mathrm{C}$ in a vacuum oven for $1 \mathrm{~h}$. Tissue sections were dehydrated in xylene and rehydrated in alcohol gradients. Endogenous 
peroxidase activity was blocked by incubating the slides in $3 \%$ hydrogen peroxide. The sections were blocked for non-specific binding with $10 \%$ normal horse serum in $1 \%$ bovine serum albumin (BSA) for $1 \mathrm{~h}$ and then blotted. Primary antibodies listed in Table 1 were applied and incubated for $60 \mathrm{~min}$. After two washings in PBS, a biotin labeled secondary antibody was applied for $30 \mathrm{~min}$ and then rinsed two times in PBS. A streptavidin/ peroxidase complex was used to bind the biotin tag and color visualization of the complex was achieved with $3,3^{\prime}$-diaminobenzidine (DAB).

\section{Results}

\section{Establishment of primary gingival keratinocytes}

Gingival epithelial cells were isolated from human gingival specimens and established in serum free 154 culture media as described in Methods. Gingival keratinocytes proliferated over time and demonstrated a cuboidal morphology, which is characteristic of gingival epithelial keratinocytes in the undifferentiated stage (Figure 1A). Cells were used at the first passage for growing raft cultures.

\section{Effect of Amprenavir on morphological differentiation and stratification of gingival keratinocytes in raft cultures}

Hematoxylin and eosin staining was performed to examine the effect of Amprenavir on gingival epithelial morphology and stratification in raft cultures. Among the numerous techniques used to culture gingival epithelial cells, the raft culture system has proven to accurately mimic the in vivo physiology of the gingival epidermis $[28,29]$. In the first set of experiments, we applied Amprenavir treatments every other day throughout the period of raft culture growth and differentiation for a total of 16 days. We treated the raft cultures with a range of Amprenavir concentrations: 2, 5, 7.66, 9 and $12 \mu \mathrm{g} / \mathrm{ml}$. Control rafts were fed with E-media only. The raft cultures treated with 2 and $5 \mu \mathrm{g} / \mathrm{ml}$ Amprenavir exhibited a dramatic dose dependent growth inhibition over time compared to untreated rafts (Figure 1B, Panels a to 1). However, the growth of gingival epithelium was completely lost at 7.66, 9 and $12 \mu \mathrm{g} / \mathrm{ml}$ of Amprenavir treatments respectively (Figure 1B, Panels $\mathrm{m}$ to $\mathrm{x}$ ). These results suggest that Amprenavir severely inhibited the growth and differentiation of gingival epithelium when the drug was present throughout the growth period. We then decided to start treating the rafts at day 8 . Under normal conditions, a developing epithelium with all 4 strata basal, spinosum, granulosum, and corneum can be visualized on collagen matrices on day 8 . Further, starting treatment on 8 day epithelium would provide the opportunity to examine the effect of this drug on developing epithelium as present in the human oral cavity. Therefore, in the second set of experiments, the rafts were treated with Amprenavir at day 8 and harvested at 2, 4, 6 and 8 days post treatment. Figure 2 demonstrates the effect of Amprenavir on day 8 gingival tissues as compared with non-treated rafts. The raft cultures treated with Amprenavir reflected the same morphology at 2 and 4 days post treatment, and were similar to untreated rafts (Figure 2, Panels a to 1). In addition, at 6 and 8 days post treatments rafts cultures treated with 2 and $5 \mu \mathrm{g} / \mathrm{ml}$ Amprenavir, the cell-cell contacts within the stratified layers appear to be less tight compared with untreated controls, thus leading to the appearance of tissues with compromised integrity (Figure 2, Panels m,n,o,s,t and u). Amprenavir at $C_{\max }(7.66 \mu \mathrm{g} / \mathrm{ml})$ and higher concentrations $(9$ and $12 \mu \mathrm{g} / \mathrm{ml})$ interfered with the epithelium stratification and compromised gingival epithelial growth and structure over time (Figure 2, Panels p,q,r,v,w and x). These results indicated that Amprenavir treatments on day 8 tissue changed the gingival epithelium differentiation and stratification affecting the integrity of epithelium. 


\section{Amprenavir treatments changes the expression pattern of differentiation markers in gingival epithelium}

A number of biochemical changes are associated with the process of terminal differentiation of gingival keratinocytes, namely, the expression of cytokeratins 5, 14 and 10 [30]. To assess the expression pattern of biochemical markers of differentiation in Amprenavir treated and untreated samples, rafts were harvested and paraffin embedded as described in Methods. Tissue sections of treated and untreated rafts were analyzed by immunostaining with monoclonal antibodies (Table 1).

Normally, cytokeratins 5 and 14 are expressed in the basal layer of gingival stratified epithelium and have been used as proliferative cell markers [30-32]. In our study, Amprenavir treatments increased and changed the expression patterns of cytokeratins 5 and 14 at 2, 4 and 6 days post treatment when compared with untreated rafts (Figure 3A and B, Panels a to r). Cytokeratins 5 and 14 were expressed throughout the layers of treated rafts compared with untreated rafts (Figures 3A and B, Panels a to r). Since cytokeratins 5 and 14 are normally expressed in the basal layer of stratified epithelium, the results of the present study suggest that Amprenavir treatments altered the cell proliferation pattern and induced a more basal like cellular environment in the upper layers which would normally be expected to have a more differentiated cellular phenotype. Amprenavir treatments severely compromised epithelium integrity at 8 days post treatment thereby making it difficult to observe the staining patterns (data not shown).

The second differentiation marker studied was cytokeratin 10 , which is normally expressed in low levels in the suprabasal layers of oral keratinocytes [25,31]. Amprenavir treatments increased and changed the expression pattern of cytokeratin 10 in a dose dependent manner (Figure 4, Panels a to r). As compared with control, Amprenavir treatments induced the expression of cytokeratin 10 in a concentration dependent manner at 2 and 4 days post treatment (Figure 4, Panels a to 1). Additionally, cytokeratin 10 expression pattern was changed in Amprenavir treated rafts at 6 days post treatment when compared with untreated rafts (Figure 4, Panels $m$ to r). These results suggest the possibility that increased expression of cytokeratin 10 at early time points may be a protective response of the epithelium towards drug induced damage.

\section{Effects of Amprenavir treatment on the expression of keratin 6}

Cytokeratin 6 expression is related with the wound healing process and is expressed in the suprabasal layer. Epidermal injury results in induced cytokeratin 6 expression in keratinocytes undergoing activation at the wounded edge [23,33]. In our study, cytokeratin 6 expression was induced at 2 and 4 days post treatment in treated rafts compared with untreated rafts (Figure 5, Panels a to 1). Cytokeratin 6 expression in treated rafts was reduced similar to untreated rafts by 6 days post treatment (Figure 5, Panels $m$ to r). Increased expression of cytokeratin 6 at 2 and 4 days post treatment possibly suggests a wound healing response of tissue against drug induced injury.

\section{Amprenavir treatments induced cell proliferation}

Since Amprenavir treatments changed the expression patterns of proliferation markers cytokeratins 5, 14 and 6, we then decided to evaluate the effect of Amprenavir on the expression of the well known cell proliferation markers PCNA and cyclin A. PCNA is a nuclear protein associated with DNA polymerase delta which is present throughout the cell cycle in proliferating cells [34]. On the other hand, cyclin A regulates entry into the DNA synthesis phase (S phase) of the cell cycle thus playing a role in the proliferation of cells $[35,36]$. Therefore, immunohistochemical analysis of PCNA and cyclin A could give a spatial view of cell proliferation. Under normal conditions, cell proliferation is limited to the 
basal layer. In our study, the PCNA and cyclin A expression in untreated rafts was limited to the basal layer at 2, 4 and 6 days post treatment (Figures 6A and B, Panels a,g and $\mathrm{m}$ ). However, in Amprenavir treated rafts, PCNA and cyclin A were strongly expressed in the basal as well as in the differentiating layers of tissue at 2 and 4 days post treatment (Figure $6 \mathrm{~A}$ and B, Panels a to 1). At 6 days post treatment, the PCNA and cyclin A expression in Amprenavir treated rafts lessened and was lost in 9 and $12 \mu \mathrm{g} / \mathrm{ml}$ of Amprenavir treated rafts (Figures 6A and B, Panels $\mathrm{n}$ to r). This observation suggests the possibility that over time tissue becomes less proliferative presumably due to the cytostatic effects of the drug. The changed expression pattern of PCNA and cyclin A indicates the activation of the wound healing pathway against drug induced damage. In addition, changed expression patterns of PCNA and cyclin A also suggest the possibility that exposure of drug induces a loss of cell cycle control which could play a role in the generation of oral complications in HIV patients under treatment with this drug.

\section{Discussion}

Oral complications have been reported to occur in HIV positive patients who are taking antiretroviral drugs especially protease inhibitors. These complications are a major health issue for those patients. Since the effect of antiretroviral drugs on oral epithelial growth and differentiation is presently unknown, therefore, in this study we studied for the first time the effect of HIV protease inhibitor, Amprenavir, on the growth of gingival epithelium, and the expression patterns of key differentiation and proliferation markers.

The growth of gingival epithelium was severely inhibited when the drug was present throughout the growth period. To our best knowledge, no data is available on the available concentration of Amprenavir in the oral cavity; however, we expect that in the oral cavity, the concentration of the drug should be at least close to or lower than its Cmax $(7.66 \mu \mathrm{g} / \mathrm{ml})$. In present study, Amprenavir even at lower concentrations ( 2 and $5 \mu \mathrm{g} / \mathrm{ml})$ severely affected the growth of gingival epithelium. These results support previous reports that indicated the use of antiretroviral drugs including protease inhibitors resulted in the development of oral complications [6,9-12]. Our observations suggest the possibility that oral epithelium in HIV patients exposed to HAART encounter drug induced abnormalities in the tissue's molecular and cellular biology which give rise to oral complications.

To examine the effect of Amprenavir on gingival keratinocytes proliferation and differentiation, we treated raft cultures at day 8. Epithelial tissues express different pairs of cytokeratin proteins depending on epithelial cell type and stage of differentiation [20,21]. Normally, gingival stratified epithelia express the cytokeratin pair of cytokeratins 5 and 14 only in the proliferative basal layer [30,32]. In current study, Amprenavir treatments increased and changed the expression patterns of cytokeratins 5 and 14 in a concentration dependent manner over time. The expression of cytokeratin 5 and 14 appeared throughout all layers of treated rafts compared with untreated rafts. Since these cytokeratins have also been shown to be enhanced in a hyperproliferative situations such as wound healing $[33,37]$; induction of cytokeratins 5 and 14 in our study may be related to a transient hyperproliferation of gingival keratinocytes following Amprenavir treatments. Further, the presence of cytokeratins 5 and 14 in the upper layers in Amprenavir treated tissues suggests the possibility that Amprenavir treatments changed pathways which regulate cytokeratins 5 and 14 expression in gingival keratinocytes.

Commitment to terminal differentiation is accompanied by a switch in keratinocyte gene expression from cytokeratins 5 and 14 to cytokeratins 1 and 10 [38]. Cytokeratin 10 is a specific terminal differentiation marker and is expressed in the suprabasal layer of keratinized epithelia. Bonan et al. [25] reported that cytokeratin 10 protects epithelium from 
trauma and damage. In the present study, Amprenavir treatments induced the expression of cytokeratin 10 in a concentration dependent manner at 2, 4 and 6 days post treatment as compared with control. It is possible that enhanced synthesis of cytokeratin 10 in drug treated gingival epithelium may be a response by the tissue to protect itself against drug induced damage $[24,25,39]$. The enhanced level of cytokeratin 10 in drug treated rafts may also be linked to strong expression of cytokeratin 10 observed in oral lesions and hyperproliferative epidermis as compared to normal epidermis [40]. Additionally, the normal balance of cytokeratin proliferation and differentiation may be disrupted upon injury and under pathologic conditions [41-43]

Induction of cytokeratin 10 expression in Amprenavir treated rafts indicated the possibility that this drug caused damage to the gingival epithelium. To prove this possibility, we studied cytokeratin 6 which is expressed in response of wound injury in the suprabasal layer of stratified epithelium. In the current study, cytokeratin 6 expression was induced significantly at 2 and 4 days post treatment in treated rafts compared with untreated rafts. Injury to stratified epithelia causes induction of cytokeratin 6 in the differentiating layers of epidermis $[23,25,33,44]$. In addition to wound healing, cytokeratin 6 is also expressed in stratified epithelia undergoing hyperproliferation or abnormal differentiation including cancer [33,45]. It is therefore possible that induced expression of cytokeratin 6 in Amprenavir treated rafts at 2 and 4 days post treatment is likely due to the wound healing attempts of the tissue after drug induced tissue damage. In addition, induction of cytokeratin 6 expression in Amprenavir treated rafts also suggests the possibility that exposure of drug induces a hyperproliferative environment in the gingival tissue. Enhanced expression of PCNA and cyclin A in drug treated rafts in our study supports these arguments. At 6 days post treatment, Amprenavir treatment specifically decreased cytokeratin 6 expression. Since cytokeratin 6 expression is generally increased in tissues undergoing wound healing, decreased expression of this cytokeratin in Amprenavir treated tissues suggests that the drug interferes with wound healing pathways upon drug induced injury. In contrast, Amprenavir treatment also interfered with proliferation and differentiation programs of gingival epithelium over time as shown by analysis of cytokeratins 5, 14 and 10 expressions. Thus, Amprenavir mediated tissue injury, unregulated proliferation, and simultaneous interference with wound healing pathways could be the one reason why HIV patients undergoing treatment with protease inhibitors including Amprenavir develop oral complications (6-11).

Increased cell proliferation is a feature of many disorders such as wounds, ulcers and human tumours, and the identification and use of reliable markers of proliferative activity is important in clinical practice [46,47]. Enhancement of cytokeratins 5, 14 and 6 expression often accompanies enhanced mitotic activity in stratified epithelia $[33,48]$, such that the former has often been taken as direct evidence for the latter. Since in the present study Amprenavir treatments changed the expression patterns of cytokeratins 5, 14 and 6 we decided to evaluate the effect of Amprenavir on the expression of the well known cell proliferation markers PCNA and cyclin A. PCNA and cyclin A are nuclear proteins which play important roles in DNA synthesis and cell cycle progression and cell proliferation. Both are generally detected in cell nuclei between the G1 and M phases of the cell cycle [35,49], and are useful histochemical markers of cell proliferation because their expression and distribution correlate with cellular proliferation rates and DNA synthesis [50]. In normal conditions of cell proliferation, PCNA and cyclin A expression is limited to a few cells in the basal layer [51,52]. In our study, PCNA and cyclin A were strongly upregulated in the basal and suprabasal layers of the drug treated tissue at 2 and 4 days post treatment. Our results suggest two possibilities. First, increased expression of PCNA and cyclin A indicates the activation of wound healing pathways to counteract drug induced tissue damage. Enhanced expression of cytokeratins 10 and 6 in drug treated rafts also supports this argument. Second, exposure to the drug deregulated the cell proliferation and differentiation 
pathways which result in abnormal proliferation and epithelial repair which could make the oral tissue more favorable for the development of oral complications observed in HIV patients taking this drug. Further, increased and altered expression patterns of cell proliferation markers including cytokeratins 5 and 14, PCNA and cyclin A indicate that the drug induces hyperproliferative growth conditions in the tissue which could make it more favorable for establishing opportunistic human papillomavirus (HPV) infections. Earlier studies have shown a significant increase in the development of HPV positive lesions in HIV patients taking HAART including protease inhibitors [6,53,54].

In conclusion, we have observed that Amprenavir severely inhibited the growth of gingival tissue when drug was present throughout the growth period. This drug changed the expression pattern of cytokeratins 5, 14, 10, 6, PCNA and cyclin A over time when drug was added at day 8. Taken together, these results suggest that Amprenavir treatments deregulated the growth, differentiation and cell cycle/proliferation pathway in human gingival tissue. Our data are supported by previous findings those reported prolonged use of protease inhibitors including Amprenavir promote several oral complications observed clinically in HIV patients. Further studies are needed to correlate these findings with detailed mechanisms of drug induced tissue damage and subsequent wound healing.

\section{Acknowledgments}

We thank Lynn Budgeon for technical assistance in preparing histological slides. We also thank Jeanette Gullet and Tracy Krouse for technical assistance in tissue processing. We are grateful to Brian Bowser, Michael Conway and Eric Ryndock for critical reading of the manuscript and helpful suggestions. This work was supported by NIDCR grant DE018305 to Craig Meyers.

\section{References}

1. Global summary of the AIDS epidemic. The Joint United Nations Programme on HIV AIDS. Dec. 2007 Available from http://data.unaids.org/pub/EPISlides/2007/2007_epiupdate_en.pdf

2. Moniaci D, Greco D, Flecchia G, Raitieri R, Sinicco A. Epidemiology, clinical features and prognostic value of HIV-1 related oral lesions. J Oral Pathol Med. 1990; 19:477-481. [PubMed: 1981079]

3. Bravo IM, Correnti M, Escalona L, Perrone M, Brito A, Tovar V, Rivera H. Prevalence of oral lesions in HIV patients related to CD4 cell count and viral load in Venezuelan population. Med Oral Pathol Oral Cir Bucal. 2006; 11:E33-39.

4. Gortmaker SL, Hughes M, Cervia J, et al. Effects of combination therapy including protease inhibitors on mortality among children and adolescents infected with HIV-1. N Engl J Med. 2001; 345:1522-1528. [PubMed: 11794218]

5. Granados JMS, Amador JTR, Miguel SF, et al. Impact of highly active antiretroviral therapy on the morbidity and mortality in Spanish human immunodeficiency virus infected children. Pediatr Infect Dis J. 2003; 22:863-867. [PubMed: 14551485]

6. Greenspan D, Canchola AJ, MacPhail A, Cheikh B, Greenspan JS. Effect of highly active antiretroviral therapy on frequency of oral warts. Lancet. 2001; 357:1411-1412. [PubMed: 11356441]

7. Greenspan JS, Greenspan D. The epidemiology of the oral lesions of HIV infection in the developed world. Oral Dis. 2002; 8:34-39. [PubMed: 12164657]

8. Hodgson TA, Greenspan D, Greenspan JS. Oral leasions of HIV disease and HAART in industrialized countries. Adv Dent Res. 2006; 19:57-62. [PubMed: 16672551]

9. Scully C, Diz Dios P. Orofacial effects of antiretroviral therapies. Oral Dis. 2001; 7:205-210. [PubMed: 11575869]

10. Diz Dios P, Scully C. Adverse effects of antiretroviral therapy: focus on orofacial effects. Expert Opin Drug Saf. 2002; 1:307-317. [PubMed: 12904130] 
11. Fagot JP, Mockenhaupt M, Bouwes-Bavinck JN, Naldi L, Viboud C, Roujeau JC. Nevirapine and the risk of Stevans-Johnson syndrome or toxic epidermal necrolysis. AIDS. 2001; 15:1843-1848. [PubMed: 11579247]

12. Jordan RA. Implications of antiretroviral therapy in oral medicine--a review of literature. Schw Mont f Zahn. 2007; 117:1210-1216.

13. Fung HB, Kirschenbaum HL, Hameed R. Amprenavir : A new human immunodeficiency virus type 1 protease inhibitor. Clin Therapeut. 2000; 22:549-572.

14. Goodgame JC, Pottage JC jr, Jablonowski H. Amprenavir in combination with lamivudine and zidovudine versus lamivudine and zidovudine alone in HIV-1-infected antiretroviral-naive adults. Amprenavir PROAB3001 International Study Team. Antivir Ther. 2000; 5:215-225. [PubMed: 11075942]

15. Rotunda A, Hirsch RJ, Scheinfeld N, Weinberg JM. Severe cutaneous reactions associated with the use of human immunodeficiency virus medications. Acta Derm Venereol. 2003; 83:1-9. [PubMed: 12636014]

16. Flint SR, Tappuni A, Leigh J, Schmidt-Westhausen AM, MacPhail L. Markers of immunodeficiency and mechanisms of HAART therapy on oral lesions. Adv Dent Res. 2006; 19:146-151. [PubMed: 16672565]

17. Hawkins T. HIV drug resistance and you. The limitations of drug resistance testing. Many factors influence the results. Posit Aware. 2006; (Spec No):13-16. [PubMed: 16596729]

18. Presland RB, Dale BA. Epithelial structural proteins of the skin and oral cavity: function in health and disease. Crit Rev Oral Biol Med. 2000; 11:383-408. [PubMed: 11132762]

19. Squier CA, Kremer MJ. Biology of oral mucosa and esophagus. J Natl Cancer Inst Monogr. 2001; 29:7-15. [PubMed: 11694559]

20. Franke WW, Schiller DL, Moll R, et al. Diversity of cytokeratins: differentiation specific expression of cytokeratin polypeptides in epithelial cells and tissues. J Mol Biol. 1981; 153:933939. [PubMed: 6177862]

21. Moll R, Franke WW, Schiller DL, Geiger B, Krepler R. The catalog of human cytokeratins: patterns of expression in normal epithelia, tumors and cultured cells. Cell. 1982; 31:11-24. [PubMed: 6186379]

22. Watanabe S, Osumi M, Ohnishi T, Ichikawa E, Takahashi H. Changes in cytokeratin expression in epidermal keratinocytes during wound healing. Histochem Cell Biol. 1995; 103:425-433. [PubMed: 7584549]

23. Paladini RD, Takahashi K, Bravo NS, Coulombe PA. Onset of re-epithelialization after skin injury correlates with a reorganization of keratin filaments in wound edge keratinocytes: defining a potential role for keratin 16. J Cell Biol. 1996; 132:381-397. [PubMed: 8636216]

24. Bloor BK, Seddon SV, Morgan PR. Gene expression of differentiation specific keratins (K4, K13, $\mathrm{K} 1$ and K10) in oral non-dysplastic keratoses and lichen planus. J Oral Pathol Med. 2000; 29:376384. [PubMed: 10972346]

25. Bonan PRF, Kaminagakura E, Pires FR. Cytokeratin expression in initial oral mucositis of head and neck irradiated patients. Oral Surg Oral Med Oral Pathol Oral Radiol Endod. 2006; 101:205211. [PubMed: 16448923]

26. Meyers C, Frattini MG, Hudson JB, Laimins LA. Biosynthesis of human Papillomavirus from a continuous cell line upon epithelial differentiation. Science. 1992; 257:971-973. [PubMed: 1323879]

27. Meyers C. Organotypic (raft) epithelial tissue culture system for the differentiation dependent replication of papillomavirus. Meth Cell Sci. 1996; 18:1-10.

28. Tomakidi P, Fusenig NE, Kohl A, Komposch G. Histomorphological and biochemical differentiation capacity in organotypic co-cultures of primary gingival cells. J Periodontal Res. 1997; 32:388-400. [PubMed: 9210093]

29. Klausner M, Ayehunie S, Breyfogle BA, Wertz PW, Bacca L, Kubilus J. Organotypic human oral tissue models for toxicological studies. Toxicol In Vitro. 2007; 21:938-949. [PubMed: 17383851]

30. Mackenzie IC, Rittman G, Gao Z, Leigh I, Lane EB. Patterns of cytokeratin expression in human gingival epithelia. J Periodontal Res. 1991; 26:468-478. [PubMed: 1722249] 
31. Eichner R, Bonitz P, Sun TT. Classification of epidermal keratins according to their immunoreactivity, isoelectric point, and mode of expression. J Cell Biol. 1984; 96:1388-1396. [PubMed: 6201491]

32. Purkis PE, Steel JB, Mackenzie IC, Nathrath WB, Leigh IM, Lane EB. Antibody markers of basal cells in complex epithelia. J Cell Sci. 1990; 97:39-50. [PubMed: 1701769]

33. Weiss RA, Eichner R, Sun TT. Monoclonal antibody analysis of keratin expression in epidermal diseases: a 48 and 56-kdalton keratin as molecular marker for hyperproliferative keratinocytes. J Cell Biol. 1984; 98:1397-1406. [PubMed: 6201492]

34. Bravo R, Frank R, Blundell PA, Macdonald-Bravo H. Cyclin/PCNA is the auxiliary protein of DNA polymerase-delta. Nature. 1987; 326:512-517. [PubMed: 2951598]

35. Pagano M, Pepperkok R, Verde F, Ansorge W, Draetta G. Cyclin A is required at two points in the human cell cycle. EMBO J. 1992; 11:961-971. [PubMed: 1312467]

36. Desdouets C, Sobczak-Thepot J, Murphy M, Brechot C. Cyclin A: function and expression during cell proliferation. Prog Cell Cycle Res. 1995; 1:115-123. [PubMed: 9552357]

37. Bernerd F, Magnaldo T, Darmon M. Delayed onset of epidermal differentiation in psoriasis. J Invest Dermatol. 1992; 98:902-910. [PubMed: 1375620]

38. Fuchs E, Green H. Changes in keratin gene expression during terminal differentiation of the keratinocytes. Cell. 1980; 19:1033-1042. [PubMed: 6155214]

39. Santos JN, Sousa SO, Nunes FD, Sotto MN, De Araujo VC. Altered cytokeratin expression in actinic cheilitis. J Cutan Pathol. 2003; 30:237-241. [PubMed: 12680953]

40. Bloor BK, Tidman N, Leigh IM, et al. Expression of keratin K2e in cutaqneous and oral lesions: association with keratinocytes activation, proliferation and keratinization. Am J Pathol. 2003; 162:963-975. [PubMed: 12598329]

41. Wetzels RH, Kujipers HJ, Lane EB, et al. Basal specific and hyperproliferation-related keratins in human breast cancer. Am J Pathol. 1991; 138:751-763. [PubMed: 1705754]

42. Morgan PR, Su L. Intermediate filaments in oral neoplasia. 1. Oral cancer and epithelial dysplasia. Eur J Cancer B oral Oncol. 1994; 30B:160-166. [PubMed: 7522710]

43. Usui ML, Underwood RA, Mansbridge JN, Muffley LA, Carter WG, Olerud JE. Morphological evidence for the role of suprabasal keratinocytes in wound reepithelialization. Wound Rep Reg. $2005 ; 13: 468-479$.

44. Mansbridge JN, Knapp AM. Changes in keratinocytes maturation during wound healing. J Invest Dermatol. 1987; 89:253-263. [PubMed: 2442269]

45. Stoler A, Kopan R, Duvic M, Fuchs E. Use of monospecific antisera and cRNA probes to localize the major changes in keratin expression during normal and abnormal epidermal differentiation. $\mathbf{J}$ Cell Biol. 1988; 107:427-446. [PubMed: 2458356]

46. Lundqvist K, Schmidtchen A. Cyclin A expression in chronic leg ulcers. Acta Derm Venereol. 2006; 86:61-62. [PubMed: 16585993]

47. Thompson PJ, Goodson ML, Booth C, Cragg N, Hamadah O. Cyclin A activity predicts clinical outcome in oral precancer and cancer. Int J Oral Maxillofac Surg. 2006; 35:1041-1046. [PubMed: 16962288]

48. Nelson WG, Sun TT. The 50- and 58-kdalton keratin classes as molecular markers for stratified squamous epithelia: cell culture studies. J Cell Biol. 1983; 97:244-251. [PubMed: 6190820]

49. Celis JE, Celis A. Cell cycle dependent variations in the distribution of the nuclear protein cyclin proliferating cell nuclear antigen in cultured cells: subdivision of S phase. Proc Natl Acad Sci USA. 1985; 82:3262-3266. [PubMed: 2860667]

50. Zuber M, Tan EM, Ryoji M. Involvement of proliferating cell nuclear antigen (cyclin) in DNA replication in living cells. Mol Cell Biol. 1989; 9:57-66. [PubMed: 2564636]

51. Bujia J, Sudhoff H, Holly A, Hildmann H, Kastenbauer E. Immunohistochemical detection of proliferating cell nuclear antigen in middle ear cholesteatoma. Eur Arch Otorhinolaryngol. 1996; 253:21-24. [PubMed: 8932424]

52. Girod SC, Pfeiffert P, Ries J, Papet HD. Proliferative activity and loss of function of tumour suppressor genes as biomarkers in diagnosis and prognosis of benign and preneoplastic oral lesions and oral squamous cell carcinoma. Br J Oral Maxillofac Surg. 1998; 36:252-260. [PubMed: 9762452] 
53. King MD, Reznik DA, O’Daniela CM, et al. Human papillomavirus associated oral warts among human immunodeficiency virus seropositive patients in the area of highly active antiretroviral therapy: an emerging infection. Clin Infect Dis. 2002; 34:641-648. [PubMed: 11803508]

54. Cameron JE, Mercante D, O'Brien M, et al. The impact of highly active antiretroviral therapy and immunodeficiency on human papillomavirus infection of the oral cavity of human immunodeficiency virus seropositive adults. Sex Transm Dis. 2005; 32:703-709. [PubMed: 16254546] 


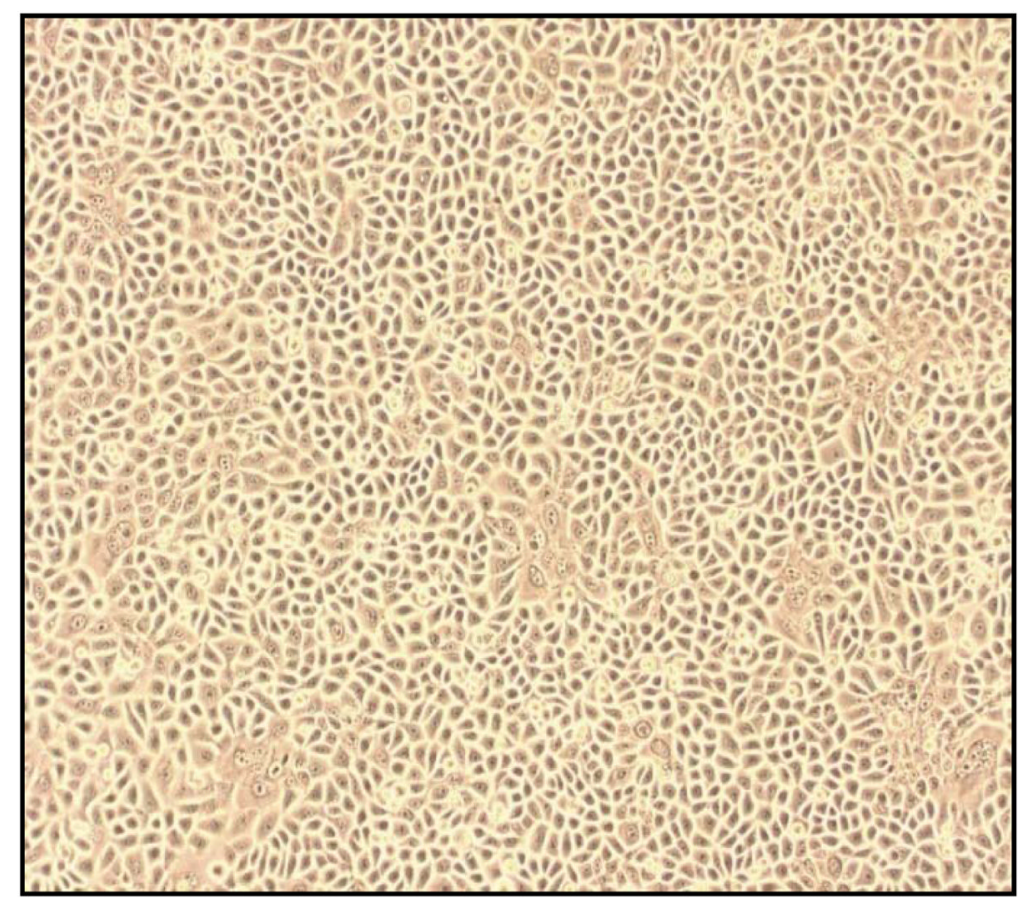

Figure 1A

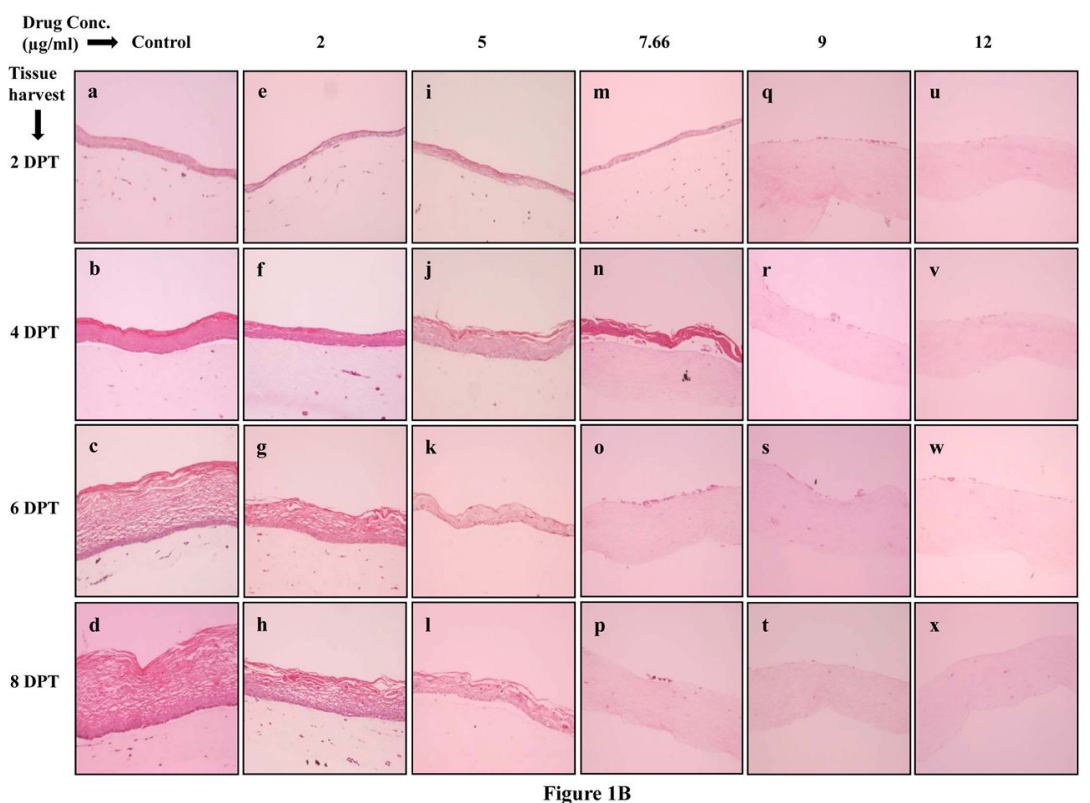

Figure 1.

(A) Cell morphology of primary gingival keratinocytes in monolayer cell culture. (B) Effect of Amprenavir on gingival epithelium growth and stratification. Primary gingival keratinocytes were grown in organotypic (raft) cultures and treated with different concentrations of Amprenavir throughout the growth period. (Panels a to d) untreated rafts; (Panels e to $\mathrm{h}$ ) rafts treated with $2 \mu \mathrm{g} / \mathrm{ml}$ Amprenavir; (Panels i to l) rafts treated with $5 \mu \mathrm{g} /$ $\mathrm{ml}$ Amprenavir; (Panels $\mathrm{m}$ to $\mathrm{p}$ ) rafts treated with $7.66 \mu \mathrm{g} / \mathrm{ml}$ Amprenavir; (Panels q to t) 
rafts treated with $9 \mu \mathrm{g} / \mathrm{ml}$ Amprenavir; (Panels u to x) rafts treated with $12 \mu \mathrm{g} / \mathrm{ml}$ Amprenavir. Rafts were harvested at different points and stained with hematoxylin and eosin. (Panels a, e, i, m, q and u) rafts were harvested at day 4; (Panels b, f, j, n, r and v) rafts were harvested at day 8; (Panels c, g, k, o, s and w) rafts were harvested at day 12; (Panels d, h, $1, \mathrm{p}, \mathrm{t}$ and $\mathrm{x}$ ) rafts were harvested at day 16 . Images are at $10 \mathrm{X}$ original magnification. DPT denotes days post treatment. 


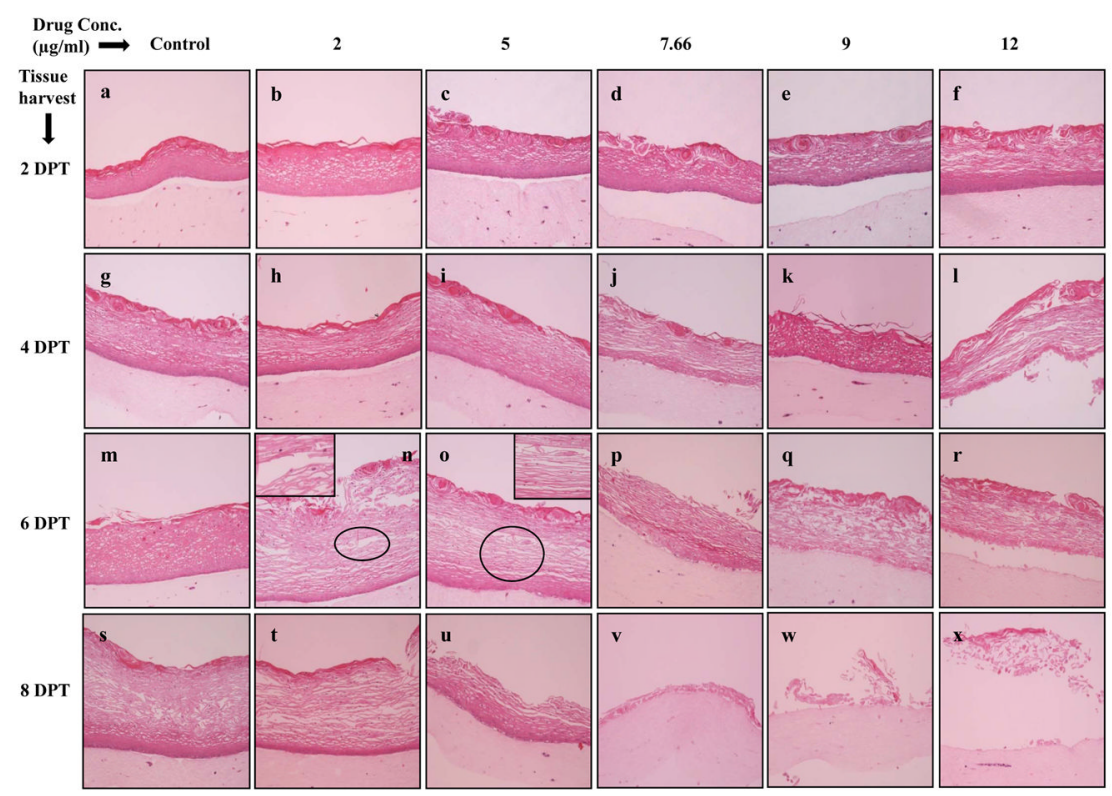

Figure 2.

Effect of Amprenavir on gingival epithelium morphology and stratification. Primary gingival keratinocytes were grown in organotypic (raft) cultures and treated with different concentrations of Amprenavir at day 8. (Panels a, g, m, and s) untreated rafts; (Panels b, h, n and t) rafts treated with $2 \mu \mathrm{g} / \mathrm{ml}$ Amprenavir; (Panels c, i, o and u) rafts treated with $5 \mu \mathrm{g} / \mathrm{ml}$ Amprenavir; (Panels d, j, p and v) rafts treated with $7.66 \mu \mathrm{g} / \mathrm{ml}$ Amprenavir; (Panels e, k, q and w) rafts treated with $9 \mu \mathrm{g} / \mathrm{ml}$ Amprenavir; (Panels f, $1, \mathrm{r}$ and x) rafts treated with $12 \mu \mathrm{g} /$ $\mathrm{ml}$ Amprenavir. Rafts were harvested at different points and stained with hematoxylin and eosin. (Panels a to f) rafts were harvested at 2 days post treatment; (Panels g to 1 ) rafts were harvested at 4 days post treatment; (Panels $\mathrm{m}$ to $\mathrm{r}$ ) rafts were harvested at 6 days post treatment; (Panels $\mathrm{s}$ to $\mathrm{x}$ ) rafts were harvested at 8 days post treatment. Images are at $10 \mathrm{X}$ original magnification. Circles in images $\mathrm{n}$ and o indicate less tight cell-cell contacts within the stratified layers or tissues with compromised integrity. DPT denotes days post treatment. 


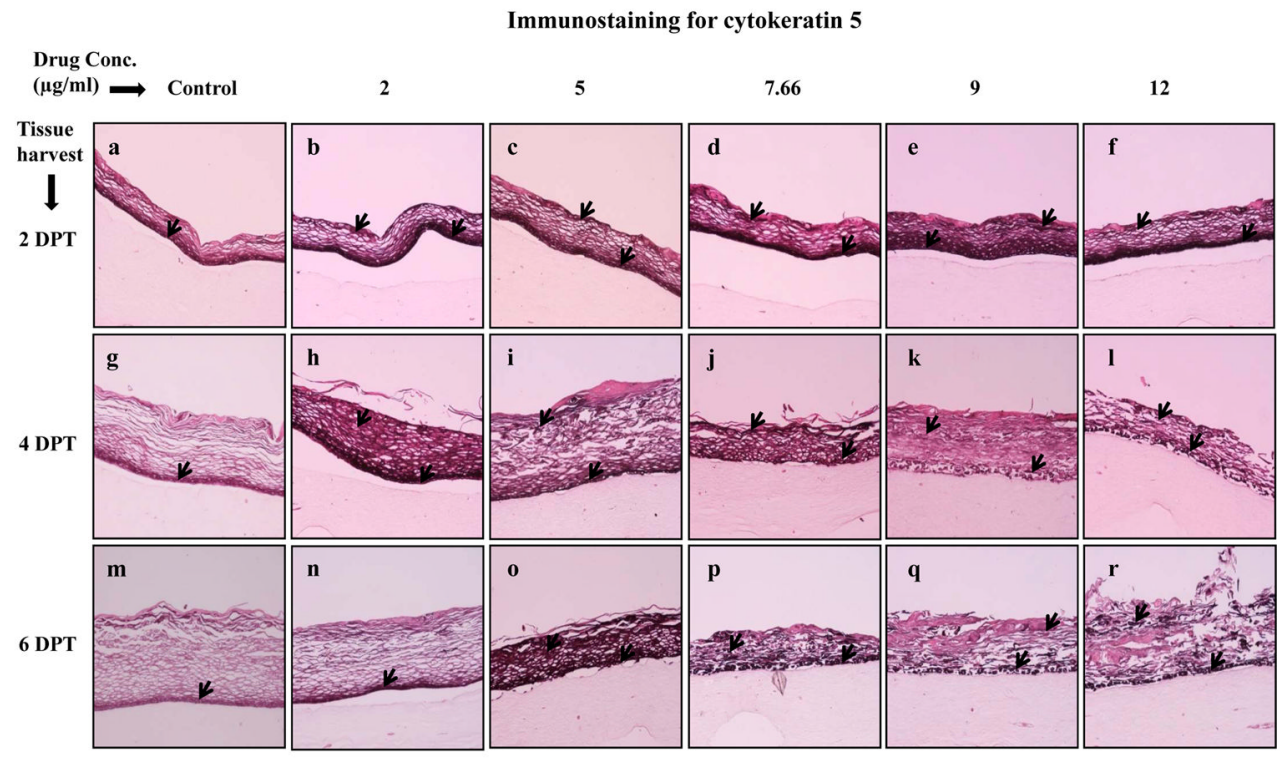

Figure 3A

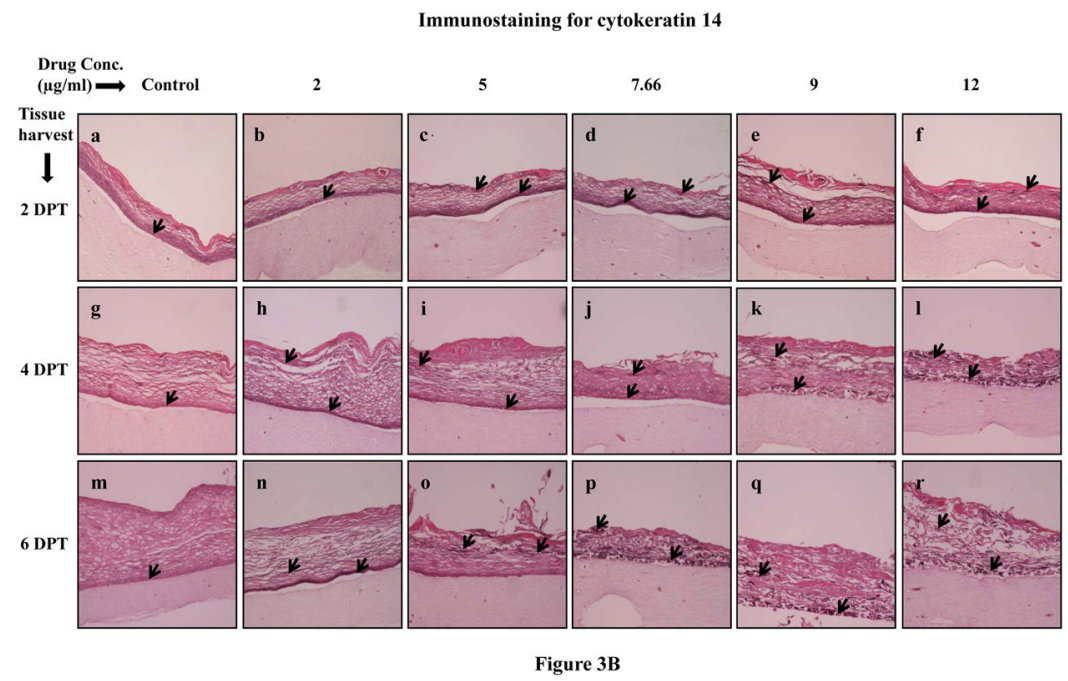

Figure 3.

Expression pattern of (A) cytokeratin 5 and (B) cytokeratin 14 in untreated and Amprenavir treated gingival raft cultures. Primary gingival keratinocytes were grown in organotypic (raft) cultures and treated with different concentrations of Amprenavir at day 8. (Panels a, g and $\mathrm{m}$ ) untreated rafts; (Panels b, h and $\mathrm{n}$ ) rafts treated with $2 \mu \mathrm{g} / \mathrm{ml}$ Amprenavir; (Panels c, $\mathrm{i}$ and $\mathrm{o}$ ) rafts treated with $5 \mu \mathrm{g} / \mathrm{ml}$ Amprenavir; (Panels d, j and p) rafts treated with $7.66 \mu \mathrm{g} /$ $\mathrm{ml}$ Amprenavir; (Panels e, $\mathrm{k}$ and q) rafts treated with $9 \mu \mathrm{g} / \mathrm{ml}$ Amprenavir; (Panels f, 1 and $\mathrm{r}$ ) rafts treated with $12 \mu \mathrm{g} / \mathrm{ml}$ Amprenavir. Rafts were harvested at different points and stained with anti-cytokeratin 5 and 14 antibody. (Panels a to f) rafts were harvested at 2 days post treatment; (Panels g to 1 ) rafts were harvested at 4 days post treatment; (Panels $\mathrm{m}$ to $\mathrm{r}$ ) rafts were harvested at 6 days post treatment. Arrows indicate the expression of cytokeratin 5 and 14. Images are at $10 \mathrm{X}$ original magnification. DPT denotes days post treatment. 


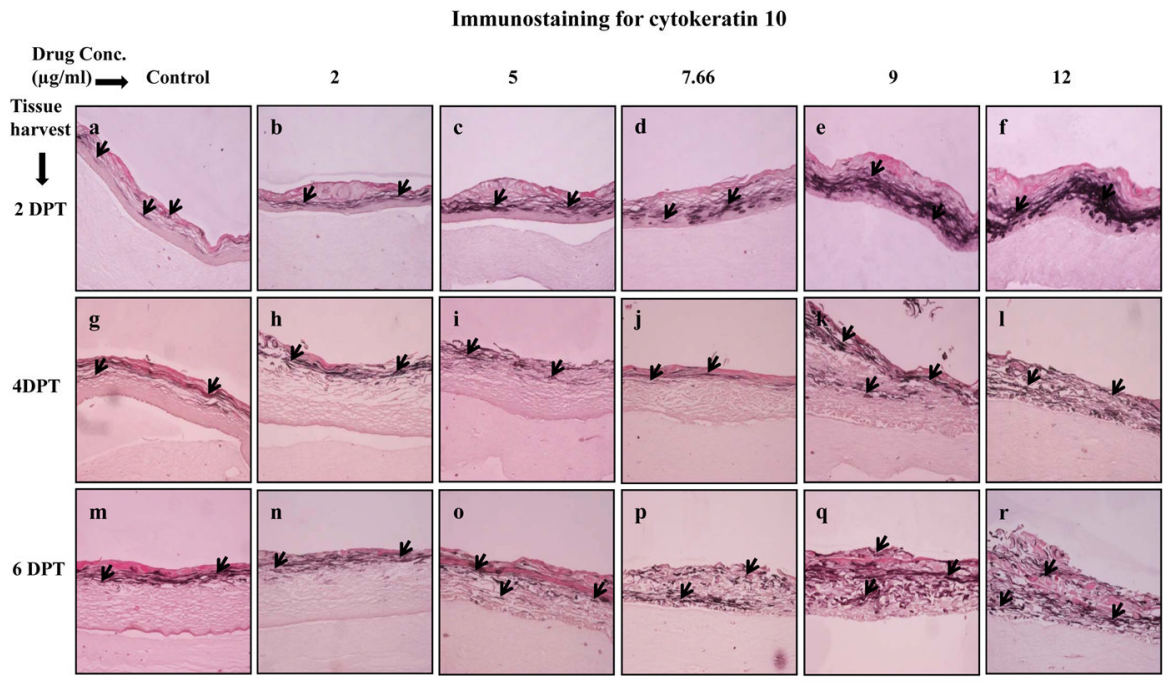

Figure 4.

Expression pattern of cytokeratin 10 in untreated and Amprenavir treated gingival raft cultures. Primary gingival keratinocytes were grown in organotypic (raft) cultures and treated with different concentrations of Amprenavir at day 8. (Panels a, $g$ and $\mathrm{m}$ ) untreated rafts; (Panels b, h and $\mathrm{n}$ ) rafts treated with $2 \mu \mathrm{g} / \mathrm{ml}$ Amprenavir; (Panels c, i and o) rafts treated with $5 \mu \mathrm{g} / \mathrm{ml}$ Amprenavir; (Panels d, j and p) rafts treated with $7.66 \mu \mathrm{g} / \mathrm{ml}$ Amprenavir; (Panels e, k and q) rafts treated with $9 \mu \mathrm{g} / \mathrm{ml} \mathrm{Amprenavir;} \mathrm{(Panels} \mathrm{f}, 1$ and r) rafts treated with $12 \mu \mathrm{g} / \mathrm{ml}$ Amprenavir. Rafts were harvested at different points and stained with anti-cytokeratin 10 antibody. (Panels a to f) rafts were harvested at 2 days post treatment; (Panels g to l) rafts were harvested at 4 days post treatment; (Panels $\mathrm{m}$ to r) rafts were harvested at 6 days post treatment. Arrows indicate the expression of cytokeratin 10. Images are at $10 \mathrm{X}$ original magnification. DPT denotes days post treatment. 


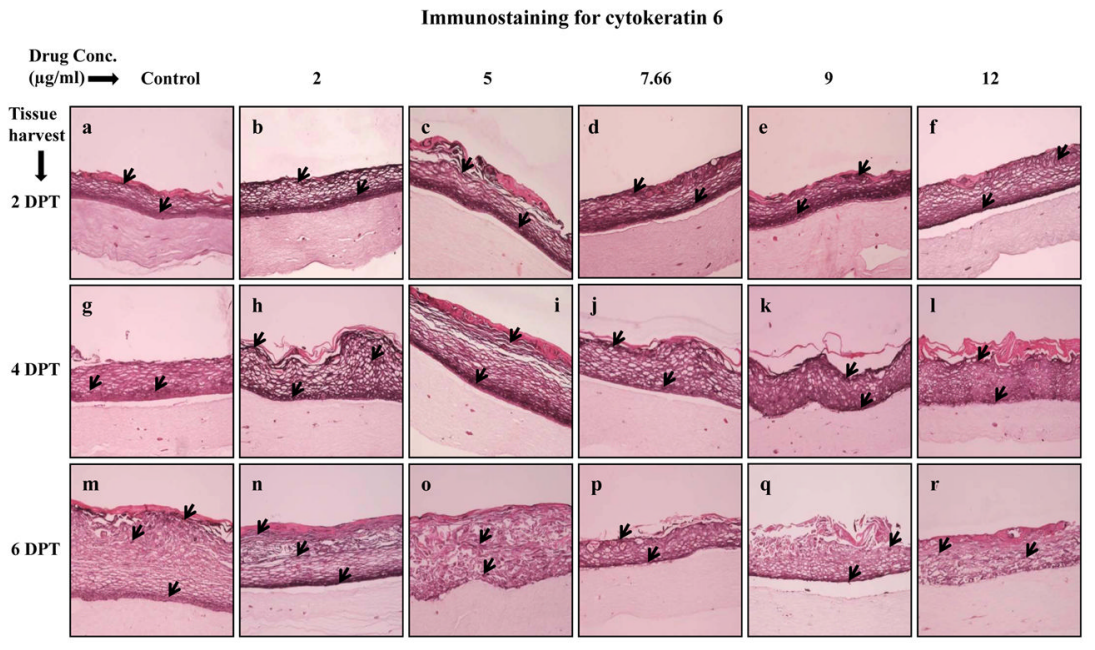

\section{Figure 5.}

Expression pattern of cytokeratin 6 in untreated and Amprenavir treated gingival raft cultures. Primary gingival keratinocytes were grown in organotypic (raft) cultures and treated with different concentrations of Amprenavir at day 8. (Panels a, $g$ and $m$ ) untreated rafts; (Panels b, h and n) rafts treated with $2 \mu \mathrm{g} / \mathrm{ml}$ Amprenavir; (Panels c, i and o) rafts treated with $5 \mu \mathrm{g} / \mathrm{ml}$ Amprenavir; (Panels d, j and p) rafts treated with $7.66 \mu \mathrm{g} / \mathrm{ml}$ Amprenavir; (Panels e, $\mathrm{k}$ and q) rafts treated with $9 \mu \mathrm{g} / \mathrm{ml}$ Amprenavir; (Panels f, 1 and r) rafts treated with $12 \mu \mathrm{g} / \mathrm{ml}$ Amprenavir. Rafts were harvested at different points and stained with anti-cytokeratin 6 antibody. (Panels a to f) rafts were harvested at 2 days post treatment; (Panels g to 1 ) rafts were harvested at 4 days post treatment; (Panels $\mathrm{m}$ to r) rafts were harvested at 6 days post treatment. Arrows indicate the expression of cytokeratin 6 . Images are at $10 \mathrm{X}$ original magnification. DPT denotes days post treatment. 


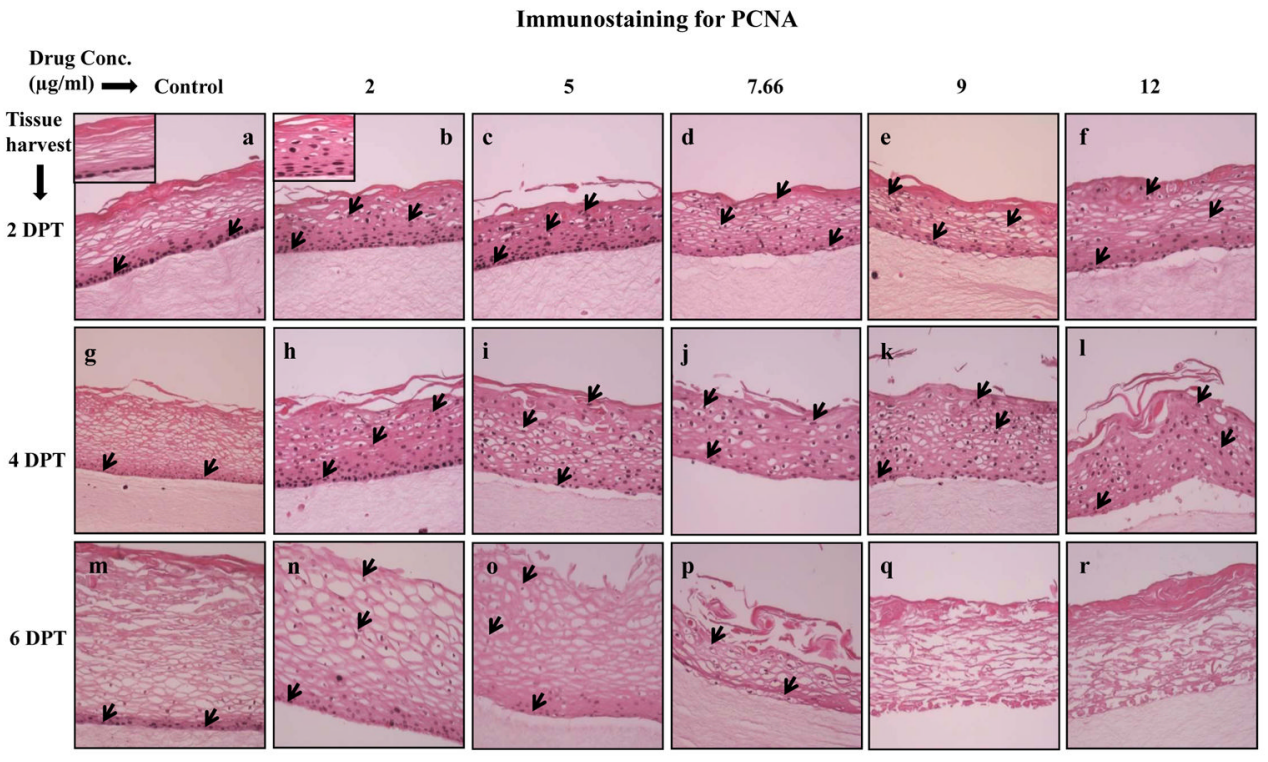

Figure 6A

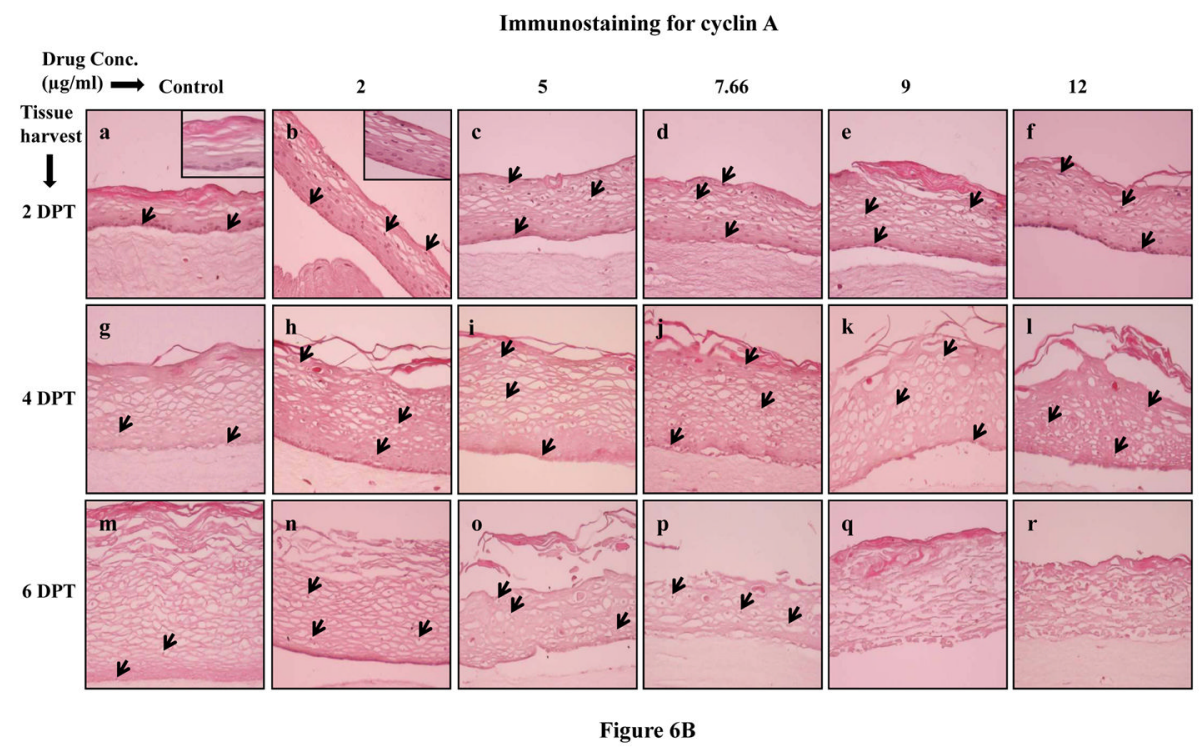

Figure 6.

(A) Proliferating cell nuclear antigen and (B) cyclin A expression pattern in untreated and Amprenavir treated gingival raft cultures. Primary gingival keratinocytes were grown in organotypic (raft) cultures and treated with different concentrations of Amprenavir at day 8 . (Panels a, g and $\mathrm{m}$ ) untreated rafts; (Panels b, h and $\mathrm{n}$ ) rafts treated with $2 \mu \mathrm{g} / \mathrm{ml}$ Amprenavir; (Panels c, i and o) rafts treated with $5 \mu \mathrm{g} / \mathrm{ml}$ Amprenavir; (Panels d, j and p) rafts treated with $7.66 \mu \mathrm{g} / \mathrm{ml}$ Amprenavir; (Panels e, $\mathrm{k}$ and q) rafts treated with $9 \mu \mathrm{g} / \mathrm{ml}$ Amprenavir; (Panels f, 1 and r) rafts treated with $12 \mu \mathrm{g} / \mathrm{ml}$ Amprenavir. Rafts were harvested at different points and stained with anti-PCNA and cyclin A antibody. (Panels a to f) rafts were harvested at 2 days post treatment; (Panels $g$ to 1 ) rafts were harvested at 4 days post treatment; (Panels $\mathrm{m}$ to $\mathrm{r}$ ) rafts were harvested at 6 days post treatment. Arrows indicate the expression of PCNA and cyclin A. Images are at $20 \mathrm{X}$ original magnification. DPT denotes days post treatment. 
Table 1

Characteristics of antibodies used.

\begin{tabular}{lllll}
\hline Antigen & Antibody & IgG Isotype & Dilution & Source \\
\hline Keratin 5 & XM26 & IgG1/k & $200 \mu \mathrm{g} / \mathrm{ml}$ & Lab Vision, Thermo Fisher Scientific, Fremont, CA, USA \\
Keratin 14 & LL002 & IgG3 & $200 \mu \mathrm{g} / \mathrm{ml}$ & Lab Vision, Thermo Fisher Scientific, Fremont, CA, USA \\
Keratin 10 & DE-K10 & IgG1 & $200 \mu \mathrm{g} / \mathrm{ml}$ & Lab Vision, Thermo Fisher Scientific, Fremont, CA, USA \\
Keratin 6 & LHK6B & IgG2a & $10 \mathrm{ng} / \mathrm{ml}$ & Lab Vision, Thermo Fisher Scientific, Fremont, CA, USA \\
PCNA & FL-261 & IgG & $2 \mu \mathrm{g} / \mathrm{ml}$ & Santa Cruz Biotechnology, Inc, Santa Cruz, CA, USA \\
Cyclin A & 6E6 & IgG1/k & $200 \mu \mathrm{g} / \mathrm{ml}$ & Lab Vision, Thermo Fisher Scientific, Fremont, CA, USA \\
\hline
\end{tabular}

